\title{
History education and citizenship conundrum: Experiences and perspectives of Lesotho General Certificate of Secondary Education history teachers in Lesotho
}

\begin{tabular}{|c|c|}
\hline \multicolumn{2}{|c|}{$\begin{array}{l}\text { Authors: } \\
\text { Raymond N. Fru }{ }^{1} \text { (1) } \\
\text { Makatleho Liphoto }\end{array}$} \\
\hline \multicolumn{2}{|c|}{$\begin{array}{l}\text { Affiliations: } \\
\text { }{ }^{1} \text { Department of Human } \\
\text { Sciences, School of Education, } \\
\text { Sol Plaatje University, } \\
\text { Kimberley, South Africa }\end{array}$} \\
\hline \multicolumn{2}{|c|}{$\begin{array}{l}\text { 2Department of Languages } \\
\text { and Social Education, Faculty } \\
\text { of Education, National } \\
\text { University of Lesotho, } \\
\text { Roma, Lesotho }\end{array}$} \\
\hline \multicolumn{2}{|c|}{$\begin{array}{l}\text { Corresponding author: } \\
\text { Raymond Fru, } \\
\text { raymond.fru@spu.ac.za }\end{array}$} \\
\hline \multicolumn{2}{|c|}{$\begin{array}{l}\text { Dates: } \\
\text { Received: } 18 \text { Oct. } 2020 \\
\text { Accepted: } 04 \text { Feb. } 2021 \\
\text { Published: } 22 \text { Apr. } 2021\end{array}$} \\
\hline \multicolumn{2}{|c|}{$\begin{array}{l}\text { How to cite this article: } \\
\text { Fru RN, Liphoto M. History } \\
\text { education and citizenship } \\
\text { conundrum: Experiences } \\
\text { and perspectives of Lesotho } \\
\text { General Certificate of } \\
\text { Secondary Education history } \\
\text { teachers in Lesotho. } \\
\text { J transdiscipl res S Afr. } \\
\text { 2021;17(1), a975. https://doi. } \\
\text { org/10.4102/td.v17i1.975 }\end{array}$} \\
\hline \multicolumn{2}{|c|}{$\begin{array}{l}\text { Copyright: } \\
\text { @ 2021. The Authors } \\
\text { Licensee: AOSIS. This } \\
\text { is licensed under the } \\
\text { Creative Commons } \\
\text { Attribution License. }\end{array}$} \\
\hline \multicolumn{2}{|l|}{ Read online: } \\
\hline 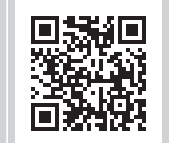 & $\begin{array}{l}\text { Scan this QR } \\
\text { code with your } \\
\text { smart phone or } \\
\text { mobile device } \\
\text { to read online. }\end{array}$ \\
\hline
\end{tabular}

There have been serious efforts across countries to make history education more relevant. One such global effort is the integration of citizenship values into the history curriculum and syllabus of schools. Despite the successes of this initiative in some contexts, others have received it with mixed feelings thereby problematising its implementation and compromising the chances of a successful outcome. This article interrogates the relationship between school history and citizenship through an exploration of the perceptions of history teachers in Lesotho about the promotion of citizenship values through history education. The rationale for the investigation stems from the inclusion of citizenship values as part of the aims of the Lesotho General Certificate of Secondary Education (LGCSE) history syllabus. The study operated within the interpretive paradigm and a qualitative case study approach of four purposively selected high schools and eight teachers in Maseru, Lesotho. The data collected from semi-structured interviews revealed that the teachers possess very vague and varying understandings of citizenship. This vagueness ultimately translates into the classroom practice in the form of a lack of harmonious implementation of the LGSCE history syllabus' prescriptions on citizenship values. The teachers however, have a mostly positive feeling about the importance of imparting citizenship values to learners, especially in the unique context of Lesotho through history education. This article recommends that the Ministry of Education and Training (MoET) initiates a robust curriculum reflection process, together with relevant stakeholders that will inform policy on the effective implementation of the citizenship clauses of the LGSCE history syllabus.

Keywords: citizenship; curriculum; history teaching; Lesotho; LGCSE.

\section{Introduction}

History is considered by some as a simplistic story of the past or a school subject that studies events over time and space. Other efforts to define history describe it as the study of people that take into account ethnic groups, social trends, religion, philosophy and political orientation. ${ }^{1}$ Whilst Ajala ${ }^{2}$ understands history as a tool used to develop peaceful coexistence in society by imparting to learners the norms and values that promote healthy human existence. Cole and Barsalou ${ }^{3}$ view history as a type of education, which promotes and secures heavily marginalised ethnic, religious and cultural identities that can easily be subjugated within the society. The views above are an insinuation that the promotion of certain values and production of good citizenry are critical in the mandate of school history. Supporting this perceived relationship between history and citizenship, $\mathrm{Fru}^{4}$ indicates that through history education, learners become responsible, reflective and active citizens who can make informed decisions. In this way, history helps learners improve their capabilities to think critically as informed citizens. Stearns ${ }^{5}$ concurs by stating that history is the subject that creates well-informed citizens about the society they live in. This significant value of citizenship education has led to a global increased interest as with many more countries embracing the discipline, either as a stand-alone subject, or as an integral part of history education. ${ }^{6,7}$ The World Education Forum ${ }^{8}$ that took place in Dakar, Senegal, analysed the social ills of contemporary society and suggested education as a powerful tool for promoting democracy, citizenship and citizenship education to curb these ills. This is recognition that education in general and history education specifically, mutually complement citizenship and citizenship education in achieving holistic development of a child and supports the quest for a decent society.

Based on the above, it became necessary that practical implications of this relationship between history and citizenship be investigated primarily through the lens of people who are mandated 
with the responsibility to ensure that the relationship succeeds. We approach this article from an experiential premise and the assumption that the way teachers perceive a programme and the level of skills they are exposed to about that programme is directly proportionate to the extent of their commitment to its implementation and the eventual success or failure. Consequently, we sought in this article to understand and interrogate the Lesotho General Certificate of Secondary Education (LGCSE) history teachers' experiences of citizenship, their perceptions on the expectation to promote citizenship values through history teaching, and problems encountered in their efforts at promoting citizenship values through the teaching of history.

\section{Background}

Subsequent to the link between citizenship and history as aforementioned, the effective implementation of the former is mainly reliant on how the latter is organised in the school set-up. In context of this article, in Lesotho history is offered at the secondary school level as an optional subject in the personal, spiritual and social learning area as reflected in the 2009 Lesotho Curriculum and Assessment Policy. ${ }^{9}$ This policy document demonstrates an apparent intention of promoting citizenship values, especially at the LGCSE level in varied ways. The curriculum and assessment policy emphasises that the overall goal of the Ministry of Education and Training (MoET) of Lesotho is to review the entire primary and secondary education curricula to make education at these levels accessible, relevant, efficient, and of the best possible quality. ${ }^{10}$ Apart from these broad goals, the curriculum goes further to provide specific aims for secondary education under which the LGCSE history syllabus is accommodated. A vital component of these aims that is relevant to this article is the idea of provision of opportunities for learners to participate in activities that promote democratic principles, human rights and emerging issues in society. ${ }^{9}$ This implies that all subjects in the curriculum, inclusive of history, should not only foster the acquisition of relevant knowledge and skills, but also values that will make students active and holistic members of their society. Furthermore, philosophical statements and expressions related to justice, equality, peace, prosperity, democracy and mutual coexistence, which underpin the way of life for the Basotho (refers to citizens of Lesotho) are to be expressed in the LGSCE.

Out of the 14 LGCSE history syllabus aims, three were identified in this article as having citizenship connotations and we, therefore, used these as the citizenship variables for this study. These three aims are presented as follows, with the numbering of the aims here corresponding to the order in which they appear in the curriculum and assessment policy: ${ }^{11}$

1.1 stimulates interest and enthusiasm for the study of the past in order to instill and develop a sense of nationality and patriotism.

1.4 inculcates ideals of tolerance as a pre-condition for the attainment of peace, stability and eventual national unity and development.
1.12 develops an awareness of environmental factors and their impact on the socio-economic and political development of Lesotho.

The inclusion of these three key citizenship-related aims in the LGCSE history syllabus indicates the importance that the curriculum and assessment policy places on the attainment of citizenship goals through history education, and constitutes part of the rationale for this article.

\section{Literature}

It is worthwhile noting as a point of departure that a desktop search of the literature revealed a study on the theme of citizenship education in Lesotho, albeit with a different focus. In that study, Tsilane ${ }^{12}$ investigates diverse approaches that can be adopted to institute a successful citizenship education programme in the Lesotho Junior Secondary Education curriculum. Whilst the above study is similar to this article, because of the common theme of citizenship exploration in the context of the education system in Lesotho, the divergence is at the level of the focuses of this article on perceptions of teachers on citizenship implementation, including their role thereof at the LGCSE level.

The meaning of citizenship is fluid and sometimes understood varyingly in different times and space. Marshall ${ }^{13}$ describes citizenship as a status bestowed upon people who were full members of a community. According to him, it required a direct sense of community membership, based on loyalty to that community, which is a collective possession. In this view, being born into a particular community qualified someone to be citizen of that community. This is also referred to commonly as citizenship by birth. Alternatively, citizenship is described as the status of a person recognised as being a legal member or part of a nation. This view deviates from the previous in terms of the focus on birth as opposed to legality, respectively. Another dimension from Herbert and Sears ${ }^{14}$ assumes citizenship as a relationship between an individual and a state, and amongst individuals within a state. Thus, citizenship refers to a person's sense of belonging within a geographical state and her relationship with other individuals within that same state.

Citizenship involves being a member of a community by enjoying its rights and having relationships with fellow citizens. Consequently, a person's citizenship is intricately linked to their identity. McLaughlin ${ }^{15}$ supports the link between citizenship and belonging to a community by alluding to minimal and maximal interpretations, with both interpretations conceived in identity in its social, cultural and psychological forms. In the 'new South Africa' for example, the official version of democratic citizenship is seen as a maximal one by positing, a citizen is one who is expected to hold an identity as a member of a democratic country, which entails not only rights but also duties. ${ }^{16}$ The vision of citizenship reflected in the Constitution of South Africa is also maximal in terms of the virtues it expects: citizens are assumed to be committed to the common good, to 
contributing to debates and decision-making at national level, as well as to the local, immediate concerns that are the focus of a more minimal conception of the citizen. ${ }^{16}$

Many scholars have conceptualised the purpose and manner of teaching and learning of history in different and sometimes conflicting ways. Scheiber ${ }^{17}$ brought up the idea of historical literacy, which refers to what an individual accumulates from studying history. One of the indicators of his historical literacy framework is the idea of citizenship. Implying that for a person to qualify as historically literate, that individual is expected to have acquired certain demonstrable core citizenship principles. Therefore, the process of learning historical concepts and historical facts can give an opportunity for pupils to develop their citizenship traits. This resonates very well with the arguments of Ajala ${ }^{2}$ and Ndille ${ }^{18}$ who argue that history affects learners' norms and values, and that history is used in certain contexts such as in Cameroon to enforce a policy of national integration which in itself is an element of citizenship. In this way, history as a subject is a tool that helps develop within a society a peaceful coexistence. Phillips $^{19}$ attests to the above arguments by suggesting that a history curriculum should encourage pupils to think independently, present sustainable arguments, communicate effectively, co-operate and learn from each other, be curious, interrogate evidence as well as be appreciative of more than one point of view and a range of different interpretations. He goes further to encourage that the history curriculum must seek to produce citizens who have a properly informed perception of their own identity as well as those of others and who actively promote inclusive, as opposed to an exclusive, view of community, society and nation. Such citizens will also be able to cultivate a depth of vision amongst pupils, addressing some universal values such as tolerance, social justice and honesty.

Despite the above visible alignment between history education and citizenship, some views however, suggest that combining both can have a few challenges. Brett ${ }^{20}$ for instance, states that there is a fear that a sustained focus on these issues will somehow take pupils away from the core business and substance of history. He further claims that the explicit teaching of citizenship in a history context may mean on occasions interweaving history and contemporary politics lessons within the context of an overarching sequence of lessons. To mitigate this impasse, Batchelor ${ }^{21}$ therefore suggests that it would be useful for citizenship coordinators to issue guidelines in order that subject specialists understand the specific requirements that education for citizenship entails. He suggests that these guidelines should make explicit how the subject they are teaching contributes to the understanding of citizenship, how it can exemplify the operation of values and concepts essential for citizenship, how it may help students to develop their skills of analysis, critical judgments, expressing a point of view or participating cooperatively with others.

\section{Methodology}

This qualitative study sought to explore Lesotho history teachers' understandings of citizenship and their perceptions of the role of history education in promoting the citizenship values embedded in the LGCSE syllabus. We approached the study from an interpretive paradigm as we assumed the subjective perspectives of the teachers to be the reality that was primordial in achieving the goals of the study through an in-depth exploration. ${ }^{22}$ Convenience and purposive sampling techniques were employed to determine participants for the study, with only schools offering history at the LGCSE level being considered. Four schools in the Maseru district were used in a proportion of two history teachers per school. We ensured that all the teachers are currently teaching history at the LGCSE level of Forms D and E.

Data was collected with the help of semi-structured interviews. These interviews were guided by the main objectives underpinning this study and were divided into four main sections. Firstly, the emphasis was on defining citizenship. Secondly, participants were asked to identify from the LGCSE history syllabus aims they thought reflected citizenship values. Thirdly, participants were asked how they teach history in order to achieve those aims identified in the syllabus. Lastly, participants were required to state challenges that they faced when addressing issues of citizenship whilst teaching history. Follow-up questions were asked as necessary. The recorded data from the interviews was thoroughly listened to and then transcribed for analysis with the teachers being given the pseudonyms A, B, C, D, E, F, G, H for purposes of anonymity. ${ }^{22}$

The analysis of the data was done inductively following the a priori thematic approach. This implies that the themes were determined by the research objectives explained in the previous paragraph. On the basis of these a priori themes, trends and patterns were identified from the teachers' responses and then analysed in a manner that was responsive to the objectives of the article. ${ }^{23}$ This was followed by a careful, more focused re-reading and review of data. Even though the themes were determined a priori, this approach to data analysis was effective because, despite LGCSE history teachers having differing views, they all relate to the research objectives, which were the main themes for this study.

\section{Ethical considerations}

The researchers ensured ethical research practice in undertaking the study. Participants were given full information about the study and requested to consent in writing before participating in the study. To ensure confidentiality, the researchers anonymised all participant names and ensured privacy. The protocols and tools of the larger Master's Degree project from which this study is drawn, were subjected to ethical review by the National University of Lesotho. 


\section{Findings and discussion}

\section{Teachers' understandings of citizenship}

All of the teachers had the requisite credentials to teach as they all held a Bachelor's Degree in Education. One teacher indicated that he holds a managerial position in his school as the head of a department (HOD). All teachers were therefore qualified to teach history in secondary schools at the LGCSE level, and could be trusted to have a wellinformed understanding of citizenship and proper familiarisation with the contents of the syllabus.

However, despite their requisite qualifications in history teaching, the findings revealed that the teachers do not necessarily demonstrate a comfortable and professional understanding of the citizenship concept. This was evident in their responses to the question of their knowledge of citizenship that was often preceded by pauses and repeating of the word citizenship. Teacher B's first response was: 'Citizenship ... citizenship is, is about emm ...' This manner of response often indicates a lack of comprehension on a topic and therefore, the absence of the correct words to explain the concept. The fact that a similar trend was observed in the responses of all the other teachers is an indication of the absence of a harmonious understanding of what the word citizenship entails and how it should be taught in the LGCSE syllabus.

The teachers, however, provided information that we were able to draw from and ascertain the kind of influence they have in their classrooms as they went about teaching history. An issue that came across strongly from the teachers is the one that links citizenship to national identity, and the rights and responsibilities that go with that. For example, Teacher B stated that to her, citizenship means '... a person's belonging to a certain country' whilst Teacher F concurred by noting that, 'citizenship is the identity of a person'. Teacher E highlighted the dimension of rights and responsibilities, which is equally linked to identity with:

'[I] have to be a Mosotho [singular form of Basotho], born in Lesotho. Even if not born in Lesotho but one who takes part in the development of the country either politically or this job that we do of teaching. That is what I understand as something I have to do also do other things to develop the country, not only myself.' (Participant E, history teacher, Maseru district)

The different reactions indicated above align the teachers' understandings to those observed by Marshall, ${ }^{13}$ Haas $^{24}$ and Ten Dam and Volman..$^{25}$ These authors argue that citizenship is being a member of a particular state and that it refers to the rights, responsibilities and actions carried out by those who belong to a community. Haas $^{24}$ submits that citizenship refers to the state of being a member of a specific state with the state as having the insiders and outsiders, the former being citizens and the latter being non-citizens. Therefore, the understandings of the teachers cited above could be summated as being physical and tangible. In their perspective, they consider the physical location of the individual with relation to their state or country of residence as being paramount in the determination of their citizenship. Going by this view, being born or living rightfully in a country qualifies one as a citizen of that country.

In addition to these views, Teachers $D$ and $G$ define citizenship through the values that they say reflects it. Teacher D for instance noted that:

'[C]itizenship entails patriotism and nationalism ... I think if I am a Mosotho, my citizenship as a Mosotho is only dependent on the extent of the love I have for my country and my ability to respect the institutions and laws of the country.' (Participant D, history teacher, Maseru district)

This prospect is quite different from those held by other teachers because it sees citizenship as fluid and intangible. It goes beyond nationality to actions individuals take in favour of the nation-state. Despite the divergent views in conceptualising citizenship, the expectation is that the exposure they give a student in their teaching and in assessment conforms to the prescriptions of the LGCSE history syllabus. Nonetheless, the extent to which these subjective understandings are managed in the history teaching process so that the syllabus takes centre stage is usually a far cry.

\section{Teachers' perspectives on history as a vehicle for citizenship education}

Issues of nationality, patriotism, tolerance, peace, stability, national unity and development that are reflected in the aims of the LGCSE history syllabus all demonstrate that history education is expected to promote citizenship values. This observation is in support of Phillips, ${ }^{19}$ who stated that history education should seek to produce learners who easily demonstrate identified citizenship competencies. This study revealed that although LGCSE history teachers showed little and varying understandings of the concept of citizenship, they however, demonstrated a positive attitude on promoting citizenship values through history education. This is encouraging considering that the class cannot reach its potential for cultivating active citizens if teachers do not have proper comprehension of that potential. Responses from all participants show the different benefits that they believe could be attained if history education is used to promote citizenship values in learners.

Amongst some of the responses in this light are, Teacher G who explained that: 'learners should be made to apply what they learn from their history lessons to their daily lives if we are to see a different generation'. What this infers is that including issues of citizenship in history lessons would help bridge the distance or historicity of the discipline of history, since citizenship, just like heritage, is about the now rather than the distant past. Putting this into practical perspective, Teacher F elaborated that:

'[T] he first place to start in trying to train children to be active citizens is by teaching them about their origin for them to know who they are and where they come from.' (Participant F, history teacher, Maseru district) 
This implies therefore, that the process of learning historical concepts and historical facts can allow pupils to develop their citizenship competencies. Supporting these positive perceptions, Ajala ${ }^{2}$ explains that history inculcates in learners significant norms and values, which can facilitate healthy human existence. In this way, history as a subject is a tool that helps develop peaceful coexistence and harmony, which are indispensable variables for any stable society.

There is a strong view from the teachers that if learners are taught citizenship values as part of their history education from a very young age, they will become better and patriotic citizens in the future. This position was held firmly by Teachers G, B and A. Teacher G noted that:

' $[I] \mathrm{f}$ learners can be taught about these citizenship values and their importance, it will be easier for them to live by them daily as they interact with their community members.' (Participant G, history teacher, Maseru district)

Teacher B concurred and advanced that:

'[C]itizenship education should be instilled in learners from an as young age as these of secondary schools so that they can grow up with the mentality that they have to protect their country at all costs.' (Participant B, history teacher, Maseru district)

This, she said is because she felt the present political leadership of Lesotho was lacking in patriotism; hence the frequent socio-economic and political troubles Lesotho is facing. She thinks it will take a generation that not only understands and appreciates the history of Lesotho but also values the Basotho identity and nation, to the extent of striving for its prosperity and development. She concluded that this could be achieved through a very aggressive and rigorous implementation of a history education in Lesotho that aligns itself squarely with core citizenship indicators. Expressing similar concern regarding the degenerating socio-political and economic situation of Lesotho, Teacher A suggested that citizenship qualities be instilled early in children in order to nurture in them a real sense of patriotism. Apart from the view amongst all these teachers that citizenship values are essential for Lesotho, there is also a general agreement that it will be more effective if it is taught in an integrated manner with history, rather than as an independent school subject. This, they think is because of the highly convergent nature of the two bodies of knowledge. We know that the past is fixed and that no one can change what happened in the past. Nevertheless, as the values of society change over time and space, the historians' depiction of the past also changes with them.

\section{Problems that the Lesotho General Certificate of Secondary Education history teachers encounter when promoting citizenship education}

The study revealed that even though the LGCSE history syllabus stipulates very clearly the requisite citizenship values and competencies that learners are expected to attain, the syllabus does not provide guidance to history teachers on how they could instruct and assess the content in order to achieve those objectives. Consequently, teachers are left to their own devices to decide and improvise on the methods and resources that could be used. It was further revealed that this lack of confidence from the teachers on how to integrate the citizenship competencies in their history lessons has a domino effect on the nature and quality of their classroom assessment. In this regard, teachers are said to provide minimal assessment opportunities, which are mostly done orally. These oral dominated assessments are compounded by unpremeditated and spontaneous questions with the hope that it will be revealed in their answers whether or not the learners have acquired the requisite citizenship competencies. Also, LGCSE history teachers' responses revealed that they believe that the MoET is only paying lip service to this initiative of integrating citizenship in history. The teachers explained that their experience of the standardised history examinations from the Examinations Council of Lesotho indicate that the examinations give more weightage to the history content areas of the syllabus, and nothing on the citizenship values and competencies. This raises concerns about the rationale for the citizenship value aims in the syllabus if they are not given equal weightage in the exams.

\section{Conclusions and recommendations}

There is no doubt that the political and socio-economic challenges currently facing the Kingdom of Lesotho would be greatly mitigated if current leadership exemplified great patriotism. It would be unsurprising to say they do not have it because they lack the kind of education that instils in citizens an understanding of the history of their country and appreciate its bearings with time, contributing to its advancement. This is the kind of education that the discipline of history, when integrated with citizenship values, can offer any nation. If the prescripts of the Lesotho curriculum and assessment policy are anything to go by, then the aforementioned is also the kind of education envisaged for Lesotho through the LGCSE history syllabus. Despite this clear history-citizenship overt syllabus prescription, its implementation is marred by significant challenges. This study revealed that whilst history teachers in Lesotho have very positive attitudes about the promotion of citizenship values in learners through history education and would love to see more effort in incorporating citizenship education in both teaching and assessment of history, they demonstrated little and, varied knowledge and understandings of the concept of citizenship. Consequent to this variance, there is a haphazard classroom implementation of the syllabus requirements. A key factor that emerged was the fact that the citizenship values expected by the syllabus are not examined by Examinations Council of Lesotho, thereby raising concerns about the seriousness of Lesotho's intentions on citizenship education.

It is recommended from this study that the MoET with the support of history Teacher Associations and other relevant stakeholders undertake a robust process of curriculum reflection. This process will interrogate and review the 
implementation of the citizenship provisions of the LGSCE history syllabus, with the ultimate goal of producing a framework for a more effective and unambiguous implementation by the history teachers. This will go a long way in supporting the curriculum and assessment policy of Lesotho to achieve the valuable purpose for which it was designed.

\section{Acknowledgements}

The authors acknowledge all the teachers who participated in this study.

\section{Competing interests}

The authors declare that they have no financial or personal relationships that may have inappropriately influenced them in writing this article.

\section{Authors' contributions}

R.N.F. and M.L. contributed equally to this work. M.L. was the Master's student. R.N.F. was the supervisor and wrote the article from the student's work.

\section{Funding information}

This research received no specific grant from any funding agency in the public, commercial or not-for-profit sectors.

\section{Data availability}

The data that support the findings of this study are available from the corresponding author, R.N.F., upon reasonable request.

\section{Disclaimer}

The views and opinions expressed in this article are those of the authors and do not necessarily reflect the official policy or position of any affiliated agency of the authors.

\section{References}

1. Weiner RG. History: Teaching and methods. TX: Eric; 1995 [document on the Internet]. No date. Available from: https://files.eric.ed.gov/fulltext/ED387402.pdf

2. Ajala EM. The influence of peace education on labour management relations in selected industries in Nigeria [unpublished doctoral dissertation]. Department of Adult Education, University of Ibadan: Ibadan; 2003.
3. Cole EA, Barsalous J. Unite or divide? The challenges of teaching History in societies emerging from violent conflict. United States Inst Peace. 2005;163(1): $1-16$.

4. Fru N. History education at crossroads: Challenges and prospects in a Lesotho context. Yesterday \& Today. 2015;13(1):67-80.

5. Stearns PN. Why study history? American Historical Association. 1998;11 [homepage on the Internet; cited 2021 Jan 20]. Available from https://www. historians.org/about-aha-and-membership/aha-history-and-archives/historicalarchives/why-study-history-(1998)

6. Print M. Civics and values in the Asia Pacific region. Asia Pacific J Educ 2000;20(1):7-20.

7. Torney-Purta J, Schwille J, Amadeo J-A, editors. Civic education across countries: Twenty-four National case studies from the IEA Civic Education Project. Amsterdam: International Association for the Evaluation of Educational Achievement (IEA); 1999.

8. World Education Forum. (2020). The Dakar framework for action: Education for all: Meeting our collective commitments [document on the Internet] [cited 2020 Feb 20]. 2020 Apr 26-28; Dakar, Senegal. Available from: https:// sustainabledevelopment.un.org/content/documents/1681Dakar\%20 Framework\%20for\%20Action.pdf

9. Ministry of Education and Training. Curriculum and assessment policy: Education for individual and social development. Maseru: MoET; 2009.

10. Raselimo M, Mahao M. The Lesotho curriculum and assessment policy. Opportunities and threats. S Afr J Educ. 2015;35(1):1-11. https://doi.org/10.15700/ 201503070025

11. National Curriculum Development Centre. Lesotho General Certificate of Secondary Education Syllabus. History 0184 [homepage on the Internet]. Examinations Council of Lesotho; 2020 [cited 2021 Feb 2]. Available from: http:// www.examscouncil.org.Is/download/syllabus/2020\%20LGCSE\%20Syllabus/ History\%20Syllabus.pdf

12. Tsilane TD. Integrating issues and aspects of citizenship education into the history curriculum for Lesotho Secondary Schools. University of Sussex: Suxxex; 2003.

13. Marshall TH, editor. Citizenship and social class. In: Sociology at the crossroads and other essays. London: Heinemann; 1963; 34-47.

14. Herbert YM, Sears AM. Citizenship education. New Brunswick: Canadian Education Association; 2001.

15. McLaughlin TH. Citizenship, diversity and education: A philosophical perspective. J Moral Educ. 1992;21(3):235-250.

16. Enslin P. Citizenship education in post-apartheid South Africa. Camb J Educ 2003;33(1);73-83. https://doi.org/10.1080/0305764032000047513

17. Scheiber HN. Recapturing a useable past: Knowledge and skills in the high school American History curriculum. Hist Teacher. 1978;1(2):481-492. https://doi. org/10.2307/492391

18. Ndille R. Learn history, think unity: National integration through History education in Cameroon, 1961-2018. Yesterday Today. 2020;23(1):44-70. https://doi.org/ 10.17159/2223-0386/2020/n23a3

19. Phillips R. Historical significance - The forgotten key element? Teaching History 2002;106(1):14-19.

20. Brett P. Citizenship through history - What is good practice? Int J Hist Learn Teach Res. 2005;5(2):10-28. https://doi.org/10.18546/HERJ.05.2.03

21. Batchelor A. Are you wearing your citizenship spectacles? Teach Citizen. 2003;5(1):34-42.

22. Cohen L, Manion L, Morrison K. Research methods in education. 7th ed. New York NY: Routledge; 2011.

23. Braun V, Clarke V. Using thematic analysis in psychology. Qual Res Psychol. 2006;3(2):77-101. https://doi.org/10.1191/1478088706qp063oa

24. Haas C. Citizenship education in Denmark: Reinventing the nation and/o conducting multiculturalism(s)? London Rev Educ. 2008;6(1):s59-69. https://doi. org/10.1080/14748460801889902

25. Ten-Dam G, Volman M. Critical thinking as a citizenship competence: Teaching strategies. Learn Instruct. 2004;14(4):359-379. https://doi.org/10.1016/j. learninstruc.2ß004.01.005 